\title{
The Influence of Competence, Independence, Interest, and Discipline on The Readiness of Working in Vocational School Students in Lombok Barat District
}

\author{
Muhammad Ridho Prihatin*, Fatwa Tentama, Budi Santosa, Aji Apri Setiawan \\ Universitas Ahmad Dahlan, Jl. Ahmad Yani, Tamanan, Banguntapan, Bantul, DIY Indonesia \\ *Corresponding author, e-mail: ridhoatin9@gmail.com
}

\begin{abstract}
This study aims to determine the effect of competence, independence, interest and discipline individually or jointly on the work readiness of vocational school students in West Lombok District. The population of this study was the students of Agro Business Competencies in Agricultural Product Processing Vocational High School in West Lombok Regency, with a sample of 67 students. Data collection uses a Likert scale questionnaire and five alternative answers. Data of all variables were analyzed with descriptive statistics with an average value of students' work readiness of $82.5 \%$. The effect of each independent variable on the dependent variable was analyzed by partial correlation statistics and multiple regression analysis. The interpretation of the results of data analysis uses a significant level of $5 \%$ or 0.05 . The results showed a very significant influence between competence, independence, interest and discipline on the work readiness of vocational students in West Lombok district with a significance value of 0,000 and a coefficient of determination of 0.462 or $46.2 \%$ meaning together the contribution of all the independent variable to the dependent variable is the remaining $46.2 \%$ of $53.8 \%$ by variables and other factors outside this study that were not explained by the researcher.
\end{abstract}

Keywords: competence, discipline, independence, interest, vocational school, work readiness.

How to Cite: Prihatin, M, R., Tentama, F., \& Santosa, B. (2020). The influence of competence, independence, interest, and discipline on the readiness of working in vocational school students in Lombok Barat district. Journal of Vocational Education Studies, 3(2), 97-110. DOI: https://doi.org/10.12928/joves.v3i2.1856.

\section{INTRODUCTION}

Law of the Republic of Indonesia Number 20 of 2003 concerning the National Education System is a conscious and planned effort to create a learning atmosphere and learning process so that students actively develop their potential to have spiritual spiritual strength, self-control, personality, intelligence, noble character, and the skills needed by himself, society, nation and country. Learning directly involves students in real practice, will have a major impact on the ability of students, so this process is what is needed by students to understand competence and the realm of work. So students must make good use of learning in industries such as industrial internship and so on to work after graduating from school later.

The Central Statistics Agency (BPS) has the highest unemployment rate for vocational high school (SMK) graduates compared to graduates from other levels of education. The unemployment rate of SMK graduates in August 2018 reached 11, 25\%. The unemployment rate is higher than February 2019 of $8.36 \%$. The data above shows that in February 2019 it was lower than the February 2018 figure of $8.92 \%$.

Initial observations were made at the Vocational School, by conducting an interview with one of the teachers at the school saying that the readiness of students to be able to work independently outside of school was still far from what was expected, students were not yet skilled in managing their own skills, they still needed other people's guidance. The 
teacher also gives an overview of the implementation of industrial learning or industrial practice of vocational schools, that students in conducting learning in industry have not shown competencies that are expected or it can be said that the results achieved are not yet optimal. Student competencies must be continuously improved through learning by gradually emphasizing skills and knowledge that are in accordance with the conditions in the field so that students are more proficient in the techniques of doing a job on target.

Discipline is a very important factor to form a person of noble character, a strong person, a person who is responsible for carrying out duties as the next generation of the nation, the school, parents all play a role in advancing and supporting the development of students, supporting students to be ready and skilled at work. This attitude makes students able to be independent in working in companies, industries and others. Prosser and Quigley (1950) explain, "vocational education will be effective in proportion as it enables each individual to capitalize his interest, aptitudes and intrinsic intelligence to the highest possible degree" The explanation above provides an understanding that vocational education will be effective in its proportion because it allows each individual to utilize their interests, talents and intrinsic intelligence to a high degree. Vocational education gives freedom to each individual to use their interest in developing their competencies.

Billet (2011) Explains "vocational education is closely aligned to the supply of abour and the kinds of capacities that these labor possesses". The statement implies that vocational education is more about the fulfillment of the workforce in accordance with the capacity of the workforce and the vocational education of competent and professional printing presses for certain types of work. Vocational education is more focused on an expertise package or on specific expertise programs that are suitable for the world of work.

Finch and Crunkilton (1999) state that "the major goal of vocational instruction is to prevent students from successful employment in the labor market". Stating that the main purpose of vocational education is to prepare students to become successful workers in the world of work. Prepare students who are ready to enter the business and industrial world. The process of students in developing professional attitudes both as workers and creating their own jobs. A very important factor for forming a person of noble character, a strong person, a person who is responsible for carrying out duties as the next generation of the nation, the school, parents all play a role in advancing and supporting the development of students, supporting the students to be ready and skilled in work. This attitude makes students able to be independent in working in companies, industries and others. Prosser and Quigley (1950) explain, "vocational education will be effective in proportion as it enables each individual to capitalize his interest, aptitudes and intrinsic intelligence to the highest possible degree" The explanation above provides an understanding that vocational education will be effective in its proportion because it allows each individual to utilize their interests, talents and intrinsic intelligence to a high degree. Vocational education gives freedom to each individual to use their interest in developing their competencies.

Billet (2011) Explains "vocational education is closely aligned to the supply of abour and the kinds of capacities that this labor possesses". The statement implies that vocational education is more about the fulfillment of the workforce in accordance with the capacity of the workforce and the vocational education of competent and professional printing presses for certain types of work. Vocational education is more focused on an expertise package or on specific expertise programs that are suitable for the world of work.

Finch and Crunkilton (1999) state that "the major goal of vocational instruction is to prevent students from successful employment in the labor market". Stating that the main purpose of vocational education is to prepare students to become successful workers in the world of work. Prepare students who are ready to enter the business and industrial world.

The Influence of Competence, Independence, Interest, and Discipline on the Readiness of Working in Vocational School Students in Lombok Barat District Prihatin, M, R., Tentama, F., \& Santosa, B. 
The process of students in developing professional attitudes both as workers and creating their own jobs.

Eric (1990) Vocational education is a multifaceted system with a diverse clientele and multiple goals, and it exists in a complex policy environment. Developing and implementing a system of performance standards for vocational education requires making demanding decisions on performance assessment, accountability, and action. This means that vocational education is a system that aspects with various components and several objectives, and is in a complex policy area. The development and implementation of a system of performance standards for vocational education requires decision making on performance appraisals, accountability, and actions.

Chalpin (2006) "Experience shows that knowledge or skills are obtained from practice or from outside the learning effort". Finch and Crunkilton (1999) "the vocational and technical education learning environment make provision for student development of Anowledge, manipulative skills, attitudes, and values, as well as the integration of these areas and their applications to simulated and realistic work settings". Hamalik (2008) Industrial work practice is a training model that aims to provide the skills needed in certain jobs according to the ability requirements for these workers.

Nurcahyono, et al (2015) explained that there are seven indicators of industrial work practices that contribute to student work readiness, namely work discipline, cooperation, initiative and creativity, responsibility, attitude, and work performance. Based on the description of the opinion above that industrial work practices must really be implemented to achieve maximum results by paying attention to the various components of the implementation of the internship learning itself, because if internship is underestimated, the learner is very disadvantaged, work readiness is very much needed later to support the careers of students after graduation.

Chalpin (2006) "readiness includes the ability to position himself if he is about to start a series of movements related to mental and physical readiness". Frantz (1997) states that "recommendations for helping youth make smooth transitions from high school to work and for further learning. Explain that recommendations to help youth make a smooth transition from high school to work and for further learning. Readiness of students is needed to achieve the desired goals.

Arikunto (2016) readiness is the competency of someone who has this competency to have adequate readiness to do something. Slameto (2013) readiness is the overall condition of a person who is prepared to give a response or answer in a certain way to a place.

Zirkle (1998) said in his research that "work skills: decision making skills, problem solving skills, creative thinking skills, teamwork skills, leadership skills, and negotiation skills". This research can be interpreted that work skills are able to decide on a decision, able to solve problems. Creative thinking, able to work together, and able to negotiate.

Cavanagh (2005) A network of business and state leaders recently identified nine skills in the workplace: (a) speaking so that others can easily understand, (b) active listening, (c) reading material with understanding, (d) cooperating with others, (e) resolving conflicts and negotiating, using mathematics to solve problems and communicate, (g) solving problems and making decisions, (h) critically observing, (i) taking responsibility for learning. The above description can be interpreted as a business network and leaders in the country related to nine skills in the workforce: (a) can communicate verbally with others clearly, (b) actively listen, (c) able to read and understand, (d) able Related to coworkers, (e) able to resolve conflicts and able to negotiate, (f) use mathematics, (g) able to make decisions quickly and accurately in solving problems, (h) discuss critically, (i) develop a passion for always study.

Work readiness is the overall condition of the individual which includes: physical, mental maturity, as well as the will, and the ability to carry out a job or activity. Brady (2010) 
job readiness is focused on personal traits, such as the nature of workers and the defense mechanisms needed, not only to get a job, but also more than that to maintain a job. Based on the description above, that work readiness must be owned based on the experiences of students at school, in the industrial environment and the place of work. Work readiness must be possessed by each individual so that when SMK students are able to become real individuals, in this case, convincing the parties with their abilities and competencies. Slameto (2013) Factors that affect readiness include three aspects, namely: (1) Physical, mental and emotional conditions. (2) needs, motives and goals. (3) Skills, knowledge and other understandings that have been learned. These three aspects affect a person's readiness to do something. Readiness of students physically or psychologically is the first step to pursue the future or curry later. Walsh (2005) states that "A variety of measures of vocational maturity have been proposed, first focusing on the exploratory stage of development, and later broadening to include adult readiness using measures such as these, researches have explored the antecedents, correlates, and consequences of vocational maturity".

Wibowo (2016) competence is an ability to carry out or carry out a job or task based on skills and knowledge and is supported by the work attitude demanded by the job. Moeheriono (2012) states that competence is a basic characteristic of someone who indicates how to think, behave, and act and draw conclusions that can be done and maintained by someone at a certain period of time. Veithzal (2009) mentions competence as skills, skills, abilities. The basic word itself, which is competent, means capable, capable, and skilled.

Fogg (2004) states that competencies are divided into two (Threshold) basic competencies and (differentiate) differentiating competencies. Threshold or basic competence is the main characteristic. Van Zolingen (2002) says "Competent workers in high-performance workplaces need: 1) basic skills in reading, writing, arithmetic, speaking, and listening. 2) thinking skills everywhere to learn, reason, think creatively, make decisions, and solve problems. 3) personal qualities - individual responsibility, selfmanagement and self-esteem, friendliness, and lawlessness ". David Mc. Clelland, who was stated by Sedarmayanti (2011) cites that competence represents the basic character that students must have, competencies that are supported directly to students, readiness and competence that can be used to improve performance and worsen it. Byars and Rue (1997) define competency as a trait or trait needed by holders of ownership in order to carry out ownership well, or also be able to distinguish individual or someone's characteristics or characteristics that are easily seen including knowledge, expertise and work.

Hurlock (2003) says that independence is a reciprocal relationship between students and the environment in which students carry out activities, develop their behavior, and others. Muyaningtyas \& Yusup (2007) stated that independence is an individual's attitudes gained cumulatively during development, while individuals will continue to learn to be able to communicate independently in environmental negotiations and eventually will be able to think for themselves. Gardner and Miller (2001) Independent learners are "... active participants in the social process of learning in class ..." Independent learners are those who are active in the process of social learning in class.

Mehta (1988) explains that to be an independent individual: "... one needs to have an ability and willingness to approach a situation with an open mind, to suspand critical judgment, and to act according to the rules and principles which are the product of the autonomous person ". Gilmore (1974) independence is an aspect of personality that must be achieved in individuals to face challenges and achieve life success that is shown by being free, responsible, having consideration, feeling safe when different from others and creativity. The characteristics of independence according to Steinberg in Desmita (2011)

The Influence of Competence, Independence, Interest, and Discipline on the Readiness of Working in Vocational School Students in Lombok Barat District Prihatin, M, R., Tentama, F., \& Santosa, B. 
are divided into three aspects: emotional independence, behavioral independence, and value independence. Demsita also conveyed the characteristics of independence which are self-determination, creative and initiative, able to regulate behavior, be responsible, be able to hold back, make their own decisions, be able to overcome problems without any influence from others.

Djaali (2008) explains that interest is the individual's acceptance of something in his environment or the relationship between oneself and something outside of that individual. Aiken (1994) defines interest as a preference for activities over other activities. Surya (2003) Interest can be interpreted as feeling happy or unhappy in dealing with an object. Winkel (2004) Said that interest is a rather settled tendency to feel attracted to certain fields and feel happy to be involved in that field. Soufia and Zuchdi (2004) interest is the driving force that causes someone to pay attention to other people, activities or other objects. Witherington (1999) states that interest is one's awareness of an object, a person, a problem or a particular situation that has to do with itself or is seen as something that is conscious. Sardirman (2014) a person's interest in an object will be more visible if the object is in accordance with the target and is related to the desires and needs of a person concerned.

Slameto (2013) several indicators of interest, namely: (a) feeling of pleasure, this aspect is related to the interest, the pleasure of individuals or students about an object in their environment, place of learning, industry and others (b) involvement, the interest of students towards the object that results learners know the object they want (c) interest, the driving force of students to have the intended object, fun or enthusiasm in the learning process and (d) attention, are stages in the process of focusing or concentration of students on a particular field or object, listen to someone talk and take notes on important points. Robertson (2013) Career guidance has commonalities with therapeutic counseling suggesting analogous effects, and it promotes positive engagement in work and learning, which may be associated with health benefits. Explain that students must really determine the desired interest for the continuity of readiness in facing work.

Veithzal (2009) explains that work discipline is a tool used by managers to communicate with employees to be willing to change a behavior and as an effort to increase one's awareness and availability in compliance with all company regulations and applicable social norms. Ariesandi (2008) explains that discipline is actually a process of gradually training the mind and character of children so that they become someone who has selfcontrol and is useful to society. Arikunto (2016) discipline is a person's obedience in obeying and following rules or regulations because it is driven by the awareness that exists in his conscience without coercion from outside parties.

Gordon (1996) discipline is behavior and order in accordance with rules and regulations, or behavior that is obtained from training that is carried out continuously. Sastrohadiwiryo (2013) states that work discipline is an attitude of respect, respect, obedience and obedience to applicable regulations, both written and unwritten and able to carry it out and not avoid taking sanctions if it violates the duties or authority given to it . Sirait (2008) states that the main purpose of a disciplinary attitude is to direct the child so that he is able to control himself, but also so that the child can carry out activities directed according to applicable regulations. Slameto (2013) says that the characteristics of people who are disciplined, namely: everyone who is always present on time at every event and obey the existing rules. Whereas Hasibuan (1997) said that people who discipline them who are always right in their time and actions, do the job well and comply with applicable rules and norms. The above opinion can be concluded that disciplined students have aspects, namely: accuracy, doing good work, obeying discipline. Based on the description above, the writer is interested in conducting research on the effect of competence, independence, interest and discipline on the work readiness of vocational students in West Lombok Regency.

Volume 3, Number 2, Nov 2020 


\section{RESEARCH METHOD}

The method used in this research is quantitative descriptive method. Sugiyono (2015) The research method is basically a scientific way to obtain valid data with the objective of finding, proving and developing knowledge so that the results can be used to understand, solve and anticipate problems. Sugiyono (2015) Quantitative research methods can be interpreted as research methods based on the philosophy of positivism, used to examine specific populations or samples. This research has been carried out on students of class XII APHP SMK in West Lombok Regency, with a total population and sample of 67. Arikunto (2016) explains that the determination of sampling as follows if less than 100 samples are better taken all, until the research is population research.

Data collection method using Sugiyono (2015) observation is a data collection technique that has specific characteristics which means it is not separated from people, but also other natural objects. Observation of this study, researchers involved with the daily activities of people being observed, next Arikunto (2016) Questionnaire is a written statement that is used to obtain information from respondents in the sense of reports about the person or things that he knows and the last documentation is wrong one method needed to obtain evidence that has occurred in the form of worksheets, drawings etc.

The variables in this study include competency, competency data for this variable is obtained from the student report card grades on productive subjects, data obtained from vocational teachers. The report card contains the value of students' knowledge and skills that are processed by taking the average value to be used as research data. Independence includes the ability to determine one's own destiny, creative and initiative, able to regulate behavior, satisfaction with one's own results, responsible, able to hold back, make their own decisions, able to overcome problems without the help of others (Desmita, 2011). Interest for the variable of interest there are several indicators that will be worked on, among others: feelings of pleasure, interest, attention, and involvement (Slameto, 2013). There are three indicators of discipline for this variable, including: accuracy, doing a good job, complying with applicable rules and norms (Hasibuan, 1997 and Slameto, 2013). Work readiness includes several indicators to be worked on including physical, mental, and emotional conditions, needs, motive needs, and goals. Knowledge, skills and other meanings (Slameto, 2013).

Data collection methods in this study were observation, questionnaire and documentation. Sugiyono (2015) observation is a data collection technique that has specific characteristics when compared to other techniques, namely interviews. Arifin (2016) suggests that the method of observation is the process of researcher involvement in observing students, then the researcher reveals all that is seen. Then the questionnaire method. Arikunto (2016) Questionnaire is a written statement that is used to obtain information from the respondent in the sense of a report about the person or things he knows. Sugiyono (2015) Questionnaire or questionnaire is a data collection technique that is done by giving a set of questions or written statements to respondents to be filled and answered. Questionnaires are needed to find out students' answers to what is the problem of the above research. Documentation, documentation method is one of the methods needed to obtain evidence that has occurred in the form of worksheets, drawings, photos of learning activities.

A valid instrument is a measuring instrument used to find answers to statements given to respondents. The validity of this instrument uses the SPSS 21 corrected item total correlation technique. The questionnaire is said to be reliable if the Cronbach Alpha value> 0.70 (Ghozali (2016). Analysis uses SPSS 21 assistance. Based on the results of the data validity test following the independence variable, of the 38 statement items determined there are 29 valid items, valid items will be used for research, and 9 items that are invalid /

The Influence of Competence, Independence, Interest, and Discipline on the Readiness of Working in Vocational School Students in Lombok Barat District Prihatin, M, R., Tentama, F., \& Santosa, B. 
fall subsequently discarded and not included for research statements, and the reliability test results of 0.960 means greater than 0.70 reliable independence variables. Interest variable, out of 23 scale items, 19 valid items were obtained and then used for research, and 4 items that were invalid / dropped were subsequently discarded, and the result of the reliability reliability test was 0.930 , which means that it was greater than 0.70 reliable interest variables.

Disciplinary variables found that of the 15 scale items obtained all valid items then used for research with the reliability test results of 917 greater than 0.70 can be said to be reliable. The work readiness variable is found that of the 20 scale items obtained all valid items are then used for research with the reliability test results of 0,947 greater than 0.70 can be said to be reliable.

\section{RESULTS AND DISCUSSION}

In general, the results of descriptive analysis obtained in the study of the average work readiness of students by $82.5 \%$. Then competence is $78.6 \%$. independence of students by $111.7 \%$, interest of students $71.4 \%$, and the last disciplinary students $62.3 \%$. The results of the classical assumption test analysis in this study, the normality test results seen from Asymp. Sig. (2-tailed) with a value of 0.834 because it is greater than 0.05 is said to be normally distributed. Linearity test results between competence and work readiness show that the value of Anova in the Deviation from Linearity section of 0.439 is greater than 0.05 , which means linear data. Furthermore, the linearity test between independence and work readiness shows that the value of Anova in the Deviation from Linearity section of 0.316 is greater than 0.05 , which means linear data. Then the linearity test between interest and work readiness shows that the value on Anova tebel in the Deviation from Linearity section of 0.920 is greater than 0.05 , which means linear data. Continued linearity test results between discipline and work readiness shows that the value of Anova in the Deviation from Linearity section of 0.104 is greater than 0.05 , which means linear data.

Table 1. Results of Multiple Regression Analysis

\begin{tabular}{ccc}
\hline Variable & \multicolumn{2}{c}{ Unstandardized Coefficients } \\
& $\mathrm{B}$ & Std. Error \\
\hline Constant & $-24,149$ & 17,918 \\
Competence & 0,224 & 0,093 \\
Independence & 0,157 & 0,047 \\
Interest & 0,563 & 0,186 \\
Dicipline & 0,504 & 0,175 \\
\hline
\end{tabular}

Based on the table above, the regression equation is obtained as follows: Work Readiness $(Y)=-24,149,+0,224 \times 1,+0,157 \times 2,+0,563 \times 3,+0,504 \times 4+e$. The equation above can be explained as follows: The results of the study show that a constant value of $-24,149$ indicates that if the variables of competence, independence, interest and discipline do not change, the work readiness variable has a value of $-22,514$. The competency variable has a regression coefficient with a positive direction of +0.224 . If it is assumed that the other independent variables are constant, this means that each increase in competence by one unit will increase the work readiness variable by +0.224 units assuming $\mathrm{x} 2$, $\mathrm{x} 3$ and $\mathrm{x} 4$ are fixed.

The independence variable has a regression coefficient with a positive direction of + 0.157. If other independent variables are assumed to be constant, this means that each increase in independence by one unit will increase work readiness by +0.157 unit with the assumptions $\mathrm{x} 1, \mathrm{x} 3$ and $\mathrm{x} 4$ fixed. Interest variables have a regression coefficient with a positive direction of +0.563 If we assume the independent variable Another constant, this means that each increase in interest variable by one unit will increase work readiness by 
$+0,563$ units assuming $x 1, x 2$ and $x 4$ are fixed. Disciplinary variables have a regression coefficient with a positive direction of +0.504 . If other independent variables are assumed to be constant, this means that each increase in discipline by one unit will increase work readiness by +0.504 units assuming $x 1, \mathrm{x} 2$ and $\mathrm{x} 3$ are fixed.

Hypothesis testing is partially used to test the significance of partial coefficients by comparing the significant count of each independent variable to the dependent variable with a significant value of $\alpha=5 \%$ or 0.05 . If the calculation is significant, count each independent variable $(\mathrm{X} 1, \mathrm{X} 2, \mathrm{X} 3, \mathrm{X} 4)<\alpha(5 \%)$. Then Ha is accepted and Ho is rejected, meaning that the independent variable influences the dependent variable. Partial test results ( $t$ test) can be seen in the following table:

Table 2. Partial Test Results

\begin{tabular}{ccc}
\hline Variable & $\mathrm{t}$ & Sig. \\
\hline Competence & 2,404 & 0,019 \\
Independence & 3,338 & 0,001 \\
Interest & 3,028 & 0,004 \\
Discipline & 2,879 & 0,005 \\
\hline
\end{tabular}

\section{Significant Influence between Competencies on Work Readiness of SMK (H1) Students.}

The competency variable has a significant influence on the work readiness of vocational students in West Lombok Regency. The results of the study using SPSS 21 can be seen in the significance section, that the significance value of $0.019>0.05$ and the value of $t$ count $=$ 2.404 is smaller than $\mathrm{t}$ table $=1$ 1.998. Calculation of $\mathrm{t}$ table as follows $=\mathrm{t}(\alpha / 2 ; \mathrm{n}-\mathrm{k}-1)=\mathrm{t}$ $(0.05 / 2 ; 67-4-1)=(0.025 ; 62)=1.99897$. The results of the study showed that Ha was accepted and Ho was rejected. The first hypothesis reads that there is a significant influence between competence on work readiness of vocational students. Good student competence depends on the process of good and sincere students, students who have good knowledge and skills will facilitate in carrying out further learning in the industry.

Readiness of students who will work is influenced by the competence of students. Good competence, the work readiness of students can be seen from their knowledge and skills, on the contrary if the competency of students is not good it will cause students to be less prepared in working. Competence of students viewed from both aspects of knowledge and skills is very good, it can be said to meet the criteria for completeness of the value obtained, so that data processed with SPSS shows the readiness of students viewed from their competence.

\section{Significant Influence between Independence on Work Readiness of Students (H2).}

There is a significant influence between independence on work readiness of vocational students. The results of the study above indicate that the significance value obtained by 0.001 means that the significance value is smaller than 0.05 and the value of $t$ arithmetic $=$ 3.338 is greater than $\mathrm{t}$ table $=1.998$. Calculation of $\mathrm{t}$ table with the following formula $=\mathrm{t}(\alpha$ / $2 ; \mathrm{n}-\mathrm{k}-1)=\mathrm{t}(0.05 / 2 ; 67-4-1) \mathrm{t}=(0.025 ; 62)=1.99897$. The calculation results show that Ha was accepted and Ho was rejected. The second hypothesis reads that there is a significant influence between independence on work readiness of vocational students in West Lombok Regency.

The Influence of Competence, Independence, Interest, and Discipline on the Readiness of Working in Vocational School Students in Lombok Barat District Prihatin, $M, R$., Tentama, F., \& Santosa, $B$. 
This research proves that independence affects the readiness of students' work, the higher and continues to improve the independence of students in doing business independently continuously, the more mature the readiness of students in entering the business world and other workplaces in accordance with the competence of their expertise . Independence is needed by students to determine readiness to work, each individual who is independent will surely be ready and skilled at work. Work readiness is required by the perseverance and tenacity of students both directly and indirectly. The results showed that independence affected the work readiness of vocational students. Counselors in schools and industry play an important role in determining the attitudes of independent learners who are able to carry out activities consciously with their abilities. Students really need direction and guidance to form this spirit of independence, these aspects must be continuously improved students to form good skills, mature readiness at work.

\section{Significant Influence between Interest in Work Readiness of Students (H3).}

There is a significant influence between interest in work readiness of vocational students. The results showed that the significance value of $0.004<0.05$ and the value of $t$ arithmetic $=3.028$ is greater than $\mathrm{t}$ table $=1.998$. Calculation of $\mathrm{t}$ table as follows $=\mathrm{t}(\alpha / 2 ; \mathrm{n}-\mathrm{k}-1)=\mathrm{t}$ $(0.05 / 2 ; 67-4-1)(0.025 ; 62) t=1.99897$. The calculation results show that Ha was accepted and Ho was rejected. The third hypothesis reads that there is a significant influence between interest in work readiness of vocational students in West Lombok Regency. The results of this study reveal that interest influences students' work readiness, interest is very inclined to preference, favor with a field, expertise, or other objects. If interest continues to be increased, the readiness and likeness of students will increase towards the object, so that interest can affect the amount of work readiness.

Interest will bring students to a comfortable zone, a zone where students will feel the most happy and happy to be in a place that suits them. Teachers must pay attention to the interests of students in determining the competencies chosen, the talent they have, so that in doing work in school and industry in accordance with their talents. Interest is the acceptance of one's relationship with the environment outside, interest has a tendency to be the pleasure and preferences of students towards the object, in this study interest influences work readiness, one's interest will determine the effect on the object which he likes and wants to do.

\section{Significant Influence between Discipline on Student Work Readiness (H4).}

There is a significant influence between discipline on work readiness of vocational students. The results of the study can be seen in the significance value, the significance value in this study is $0.005<0.05$ and the calculated $t$ value $=2.879$ is greater than the $t$ table $=1.998$. Calculation of $\mathrm{t}$ table in this study as follows $=\mathrm{t}(\alpha / 2 ; \mathrm{n}-\mathrm{k}-1)=\mathrm{t}(0.05 / 2 ; 67-4-1)=(0.025$; $62)=1.99897$. Based on these calculations it can be interpreted that Ha is accepted and Ho is rejected. The fourth hypothesis reads that there is a significant influence between discipline on work readiness of vocational students in West Lombok Regency. Discipline has a positive influence on work readiness, discipline is the result that is expected by researchers through a predetermined hypothesis.

Teachers and those who play a role in determining the attitudes and behavior of students must continue to be maintained in order to prepare students who are superior, mature in work. Learners must pay attention to several factors, aspects and habits. Students' work readiness is seen from their discipline, the more disciplined students are improved, the higher the work readiness of the students themselves. Discipline is always related to aspects of work readiness, when students are disciplined in school, industry and other workplaces, then readiness and maturity to enter the business and industrial world 
are met. Work discipline that is grown by individuals both in schools and industries will be the main capital of students facing the real work after graduation.

Hypothesis testing is simultaneously used to test the effect of independent variables namely competence, independence, interest and discipline together on the dependent variable that is the work readiness variable of vocational students with a significance level of $\alpha=5 \%$ or 0.05 . If the calculation is significant $<\alpha(5 \%)$ then Ha is accepted Ho is rejected, meaning that the independent variable influences the dependent variable. The results of the $\mathrm{F}$ test in this study are as follows:

Table 3. Simultaneous Test Results

\begin{tabular}{cc}
\hline $\mathrm{F}$ & Sig. \\
\hline 15,173 & $0.000^{\mathrm{b}}$ \\
\hline
\end{tabular}

Based on the test results in the above table it can be seen that the significance value of $0,000<0.05$ and the calculated $F$ value of 15.173 is greater than the $F$ value of the table 2.52 , it can be said that $\mathrm{Ha}$ is accepted and Ho is rejected. The hypothesis jointly or simultaneously reads that there is a very significant influence between competence, independence, interest, and discipline on the work readiness of vocational students in West Lombok Regency. The above research results show that the results of the hypothesis test can simultaneously be seen from the above calculations and their significance value, competence, independence, interest and discipline are deemed necessary to be improved within individual students.

The coefficient of determination essentially measures how far the model's ability to explain the variation of the dependent variable. The coefficient of determination close to one means that the independent variables provide almost all the information needed to predict the variation of the dependent variable. The coefficient of determination (Adjusted $\mathrm{R}$ Square) seen in the following table shows the ability of multiple regression equations to show the level of explanation of the model of the dependent variable. This means how much the contribution of the indefendent variable to the devendent variable. The results of the coefficient of determination $(R 2)$ are presented in the following table:

Table 4. Determination Coefficient Test Results $\left(R^{2}\right)$

\begin{tabular}{cc}
\hline R Square & Adjusted R Square \\
\hline 15,173 & $0.000^{\mathrm{b}}$ \\
\hline
\end{tabular}

Based on the table above, the coefficient of determination is found in Adjusted $\mathrm{R}$ Square of 0.462 or $46.2 \%$ which means that the ability of the dependent variable that is work readiness can be explained by four independent variables namely competence, independence, interest, and discipline. While the rest (100\% - 46.2\%) so 53.8\% is explained by other variables not included in the regression model.

This research reveals that job readiness is not just about knowledge and skills. Work readiness is closely related to these predictor factors. How students are able to develop and execute well all aspects and continuously with seriousness such as competence, aspects of independence, the level of discipline, and good interest. The results of this study as a whole are proven that all four variables influence the work readiness. The competency aspect is needed to strengthen the work readiness of students, the competence of students cannot be seen from the value of report cards only, but the competence of students must be viewed

The Influence of Competence, Independence, Interest, and Discipline on the Readiness of Working in Vocational School Students in Lombok Barat District Prihatin, M, R., Tentama, F., \& Santosa, B. 
from other factors that influence, the results do not undermine the process, but in reality the closeness of individuals with others will defeat the process. Competence should have an influence on work readiness by showing seriousness in the field, giving a picture that the real knowledge and skills are seen from the skill and failure of students in the field.

Independence is a component that strongly supports work readiness to strengthen the value of students' knowledge and skills, the more self-reliance is, the more work readiness of students increases. Independence is an important factor also in increasing students' work readiness. This aspect will determine once understanding in getting to know the skills deeper, thus the readiness of students will be more mature. The interest of students in megenal objects is largely determined by understanding in understanding the field, students' interest in objects must be based on an initial introduction to what fields are learned in them. Interests must be in accordance with the object and what will be implemented. The greater the interest of students towards an object or expertise competency, the greater the level of work readiness. Discipline is seen as an important factor as well, without the discipline of students will not be able to become a person who is ready to work. The work readiness of vocational students will increase if factors such as discipline continue to be improved in learning in schools and in industry.

\section{CONCLUSION}

This study concludes that competence, independence, interest and discipline are factors that greatly determine the readiness of students' work, independence will help students to act without orders and help from others, discipline will foster patriot soul and high selfconfidence and interest will bring a sense of interest and pleasure in what is done. The partial data of the results of this study:

1. Competence has a significant effect on the work readiness of vocational students in West Lombok Regency. The results of research using SPSS 21 can be seen in the significance section, that the significance value is $0.019>0.05$. The results of the study showed that Ha was accepted and Ho was rejected. The hypothesis reads that there is a significant influence between competence on work readiness of vocational students.

2. Independence significantly influences work readiness. The results of the above study indicate that the significance value obtained by 0.001 , indicates that the significant value is less than 0.05 . So it can be concluded that Ha was accepted and Ho was rejected. The hypothesis reads that there is a significant influence between independence on work readiness of vocational students in West Lombok Regency.

3. There is a significant influence between interest in work readiness of vocational students. The results showed that the significance value of $0.004<0.05$. The calculation results show that Ha was accepted and Ho was rejected. The hypothesis reads that there is a significant influence between interest in the work readiness of vocational students in West Lombok Regency.

4. There is a significant influence between discipline on work readiness of vocational students. The results of the study can be seen in the significance value, the significance value in this study was $0.005<0.05$. Based on the explanation above it can be interpreted that Ha was accepted and Ho was rejected. The hypothesis reads that there is a significant influence between discipline on work readiness of vocational students in West Lombok Regency.

5. Competence, independence, interest and discipline together have a very significant influence on the work readiness of vocational students in West Lombok Regency. The result of the research is that the significance value is simultaneously $0.000<0.05$ then $\mathrm{Ha}$ is accepted and Ho is rejected. The hypothesis jointly can be concluded that the competency variables $\left(\mathrm{X}_{1}\right)$, independence $\left(\mathrm{X}_{2}\right)$, interests $\left(\mathrm{X}_{3}\right)$, and discipline $\left(\mathrm{X}_{4}\right)$ together or simultaneously have an effect which is very significant to the work readiness (Y) of SMK students in the District West Lombok. 
The coefficient of determination in this study was $46.2 \%$, namely work readiness can be explained by four independent variables namely competence, independence, interest, and discipline. While the remaining $53.8 \%$ is explained by other variables not included in this study.

\section{REFERENCES}

A. M, Sardirman. (2014). Interaction and Teaching and Learning Motivation. Jakarta: Rajawali Press.

Aiken, Lewis R. (1994). Pshycological Testing And Assessment. Boston. Allyn and Bacon.

Ariesandi. (2008). Secrets of Educating Children to be Successful and Happy, Tips and Praise Skyline Optimal Children. Jakarta: PT Gramedia Pustaka Utama.

Arifin, Zaenal. (2016). Learning Evaluation. Bandung: PT. Teen Rosdakarya Offset.

Arikunto, Suharsimi. (2016). Research Procedure A Practical Approach. Jakarta: Rineka Cipta.

B. Renita., Muyaningtyas., \& Yusup., Purnomo, H. (2007). Guidance and counseling for high school and MA in class XI. Jakarta: Erlangga.

Billet, Stephen. (2011). Vocational Education. Australia: Griffith University.

Brady, Robert. P. (2010). Work Readiness Inventory. Indianapolis: JIST Works.

Byars, Liyoled L, and Rue, Leslie W. (1997). Human Resources Management. 5th Ed. McGrawHill, USA.

Cavanagh, Sean. (2005). Concept of Work Readines Credential Gains Supporters. ProQuest Educations Journals. Vol. 2, No.4, Pg. 19-24.

Chalpin, John Paul. (2006). Complete Dictionary of Psychology (Kartini Kartono Translation). Jakarta: PT Raja Grafindo Persada.

Desmita. (2011). Developmental Psychology of Students. Bandung: Rosda works.

Djaali (2008). Educational Psychology. Jakarta: Earth Literacy.

Eric. (1990). Vocational Education Performance Standards. Accessed November 10, 2019 http: //www.Vocational education performance standards. ERIC. Htm digest.

Finch, Curtis R and Crunkilton, John R. (1999). Curiculum Development in Vocational and Technical Education: Planning, Content, and Implementation (5th). Boston. Allyn and Bacon.

Fogg, Milton. (2004). The Greatest Networker in the World. The Three Rivers Press: New York.

Frants, Nevin. R., Jr. (1997). The Identifications of National Trends and Issues for Workplace Preparations and Their Implications for Vocational Teacher Educations. Journal of Vocational and Technical Education. Vol.14 No.1. Pg. 8-19

Gardener, David and Miller, Lindsay. (2001). Establishing Self Access From Theory to Contract. Cambridge: Cambridge University Press.

Ghozali, Imam. (2016). IBM SPSS 23 Multivariate Analysis Application (8th Edition). Semarang: Diponegoro University Publisher Agency.

Gilmore, John V. (1974). The Productive Personality. San Francisco: Albion.

Gordon, Thomas. (1996). Teaching Children to Self-Discipline at Home and at School. Jakarta: PT Gramedia Pustaka Utama.

Hasibuan, J.J and Moedjiono. (1997). Teaching and Learning Process. Bandung: Teen Rosdakarya.

The Influence of Competence, Independence, Interest, and Discipline on the Readiness of Working in Vocational School Students in Lombok Barat District Prihatin, M, R., Tentama, F., \& Santosa, B. 
Hurlock, Elizabeth. (2003). Developmental Psychology. Jakarta: Erlangga.

Mehta, Manju. (1988). Behavioral Sciencies in Medical Practice. New Delhi: Jaypee Brother Medical Publisers.

Moeheriono. (2012). Competency Based Performance Estimator. Jakarta: Grafindo Persada.

Nurcahyono, Eko \& Yanto, Heri. (2015). Industrial Work Practices and Their Contribution to Work Readiness. Economic Education Analysis Journal. Vol. 4, No. 1, 194-202.

Oemar, Hamalik. (2008). Curriculum and Learning. Jakarta: Earth Literacy.

Prosser, Charles A. \& Quigley, Thos H. (1950). Vocational Education in a Democracy. Revised Edition. Chicago: American Technical Society.

Rivai, Veithzal. (2009). Human Resource Management. Jakarta: Raja Grafindo Persada.

Robertson, Peter J. (2013). The Well-being Outcomes of Career Guidance. British Journal of Guidance and Counseling. Vol. 41, No. 3. PG 254-266.

Sastrohadiwiryo, Siswanto. (2013). Indonesian Workforce Management. Administrative and Operational Approach. Jakarta: Earth Literacy.

Awarmayanti. (2011). Human Resources and Work Productivity. Bandung: Mandar Forward.

Sirait, Justine. T. (2008). Understanding the Aspects of Human Resource Management in Organizations. Jakarta: Grasindo.

Slameto (2013). Learning and Factors That Influence It. Jakarta: Rineka Cipta.

Soufia, Ana Laila and Zuchdi. (2004). Interest in Learning and Implementation. Yogyakarta: Yogyakarta State University.

Sugiyono (2015). Educational Research Methods A Qualitative, Quantitative and R\&D Approach. Bandung: Alfabeta.

Surya, Mohamad. (2003). Counseling Psychology. Bandung: Library of the Children of Quraysh.

Law Number 20 of 2003 Concerning the National Education System.

Walsh, W. Bruce and Savicks, Mark. (2005). Handbook of Vocational Psychology Theory, Reasech and Practice (3nd ed). London: Lawrence Erlbaum Associates Publishers.

Wibowo. (2016). Performance Management, Fifth Edition. Jakarta: PT. Raja Grafindo Persada.

Winkel, W. S. (2004). Educational Psychology and Learning Evaluation. Jakarta: PT. Gramedia Main Library.

Zirkle, Chris. (1998). Perceptions of Vocational Educators and Human Resources/Training and Development Professionals Regarding Skill Dimensions Of School-To-Work Transition Programs. Journal of Vocational and Technical Educations. Vol.15, No.1, Pg. 50-62.

Zoligen, Van SJ. (2002). The Role of Key Qualifications in the Transition from Vocational Education to Work. Journal of Vocational Education Research. Vol.27. No. 2 Pg. 217242. 